\title{
A prosztatarák molekuláris altípusai és célzott terápiás kilátásai
}

\author{
Szarvas Tibor dr.* - Csizmarik Anita* \\ Szǘcs Miklós dr. - Nyirády Péter dr. \\ Semmelweis Egyetem, Általános Orvostudományi Kar, Urológiai Klinika, Budapest
}

\begin{abstract}
A nagy áteresztőképességű molekuláris vizsgálómódszereknek az elmúlt évek során végbement rohamos fejlődése lehetôvé tette a tumorok genetikai, epigenetikai, transzkriptom- és fehérjeszintú molekuláris hátterének átfogó és mélyreható elemzését. A nagyszámú tumormintán elvégzett vizsgálatok óriási mennyiségú adatot szolgáltattak, melyek klinikai szempontból történő feldolgozása, értelmezése jelenleg még zajlik, de már most is jelentős új felismerésekhez járult hozzá. Az ilyen típusú kutatások a közelmúltban a prosztatarák esetében is azonosították azokat a legfontosabb molekuláris eltéréseket, melyek szerepet játszanak e tumor kialakulásában és progressziójában. Összefoglaló munkánkban áttekintést nyújtunk a primer és az előrehaladott prosztatarák közelmúltban kidolgozott molekuláris alcsoportbeosztásáról, valamint a leggyakrabban sérült jelátviteli utakról, úgymint az androgénreceptor-, PI3K-, sejtciklust szabályozó útvonalakról és a DNS-hiba-javító mechanizmusokról. Ennek kapcsán áttekintjük a prosztatarák genetikai eltéréseire tervezett célzott terápiás szerek már alkalmazott, valamint még klinikai kipróbálás alatt álló típusait.
\end{abstract}

Orv Hetil. 2019; 160(7): 252-263.

Kulcsszavak: prosztatarák, molekuláris altípus, célzott terápia, genetikai eltérés, mutáció

\section{Molecular subtypes and perspectives of targeted therapies in prostate cancer}

In the last few years, the emergence of new high throughput molecular technologies allowed a never-before-seen insight into the genetic, epigenetic, transcriptomic and proteomic background of cancers. These studies have been performed in a large number of patients' samples and provided a great amount of data. Current efforts to translate these new findings into therapeutic strategies are ongoing, but already provided significant information which may change clinical practice in the near future. As a result of this development, the most frequent molecular alterations and affected pathways responsible for the formation and progression of prostate cancer have been identified. In this review, we provide an overview on the current progress in primary and metastatic prostate cancer research focusing on the molecular subtype classification and the most frequently dysregulated pathways, such as androgen signaling, PI3K pathway, cell cycle and DNA repair regulation. In this context, we highlight therapies already approved or are currently under clinical investigation for prostate cancer.

Keywords: prostate cancer, molecular subtype, targeted therapy, genetic aberration, mutation

Szarvas T, Csizmarik A, Szücs M, Nyirády P. [Molecular subtypes and perspectives of targeted therapies in prostate cancer]. Orv Hetil. 2019; 160(7): 252-263.

(Beérkezett: 2018. szeptember 22.; elfogadva: 2018. október 9.)

*A két szerző egyenlő mértékben járult hozzá a cikk megszületéséhez.

\section{Rövidítések}

$\mathrm{APC}=$ adenomatosus polyposis coli $\mathrm{AR}=($ androgen receptor $)$ androgénreceptor; ATM = (ataxia telangiectasia mutated $)$ ataxia telangiectasia mutált; ATR $=$ (ataxia telangiectasia and rad3related) ataxia telangiectasia és rad3-kapcsolt; BAY1895344 =
ATR-inhibitor; BER = (base excision repair) bázikus excíziós javítás; BRCA2 = (breast cancer type 2$)$ emlőrákra hajlamosító gén 2 -es típusa; $\mathrm{CCNDI}=($ cyclin Dl $)$ ciklin Dl; $\mathrm{CCTNBI}=$ $(\beta$-catenin $) \beta$-katenin; CDK12 $=($ cyclin dependent kinase 12$)$ ciklindependens kináz-12; CDK4-6 = (cyclin dependent ki- 
nase 4-6) ciklindependens kináz-4-6; CDKN2A = (cyclin dependent kinase inhibitor $2 \mathrm{~A}$ ) ciklindependenskináz-inhibitor$2 \mathrm{~A} ; \mathrm{CHDl}=($ chromodomain-helicase-DNA-binding protein 1) kromodomén-helikáz DNS-kötő fehérje-l; CHKl = (ATRcheckpoint kinase 1) ATR-checkpoint-kináz-1; CRPC = (castration-resistant prostate cancer) kasztrációrezisztens prosztatarák; $\mathrm{DNS}=$ (deoxyribonucleic acid) dezoxiribonukleinsav; ELK4 $=($ ETS domain-containing protein Elk-4) ETS-doméntartalmú fehérje Elk-4; ERG = (ETS-related gene) ETS-kapcsolt gén; ETS $=$ erythroblast transformation-specific; ETV = ETS translocation variant; FANCA $=$ Fanconi-anaemia, complementation group A; FANCD2 = Fanconi-anaemia, complementation group $\mathrm{D}_{2} ;$ FANCJ $=$ Fanconi-anaemia, group J; FDA $=$ (U.S. Food and Drug Administration) az Amerikai Egyesült Államok Élelmiszer-biztonsági és Gyógyszerészeti Hivatala; FOXAl = forkhead box-Al; GDC-0980 = AKT-inhibitor; GSK2636771 = PI3K- $\beta$-inhibitor; GSTPl $=$ (glutathione $S$-transferase Pl) glutation-S-transzferáz-Pl; IDHl = (isocitrate dehydrogenase 1 ) izocitrát-dehidrogenáz-1; KMT2C = (lysine $\mathrm{N}$-methyltransferase 2C) lizin- $\mathrm{N}$-metiltranszferáz-2C; KMT2D $=$ (lysine methyltransferase 2D) lizin-metiltranszferáz-2D; LGK974 $=$ porcupininhibitor; L-MYC $=($ myc-related gene) myc-kapcsolt gén; mCRPC $=$ (metastatic castration-resistant prostate cancer) metasztatikus kasztrációrezisztens prosztatarák; $\mathrm{MLH1}=$ MutL-homológ-1; MMR = mismatch repair MSH2 $=$ MutS protein-homológ $-2 ;$ MSI $=$ (microsatellite instability) mikroszatellitainstabilitás; $\mathrm{mTOR}=(\mathrm{mammali}-$ an target of rapamycin) emlös rapamicincélpont; NCOR1, -2 = nuclear receptor corepressor- $1,-2 ; \mathrm{NER}=$ (nucleotide excision repair) nukleotidexcíziós javítás; PARPl $=($ poly[ADP-ribose $]$ polymerase 1$)$ poli(ADP-ribóz) polimeráz-1; PC $=$ (prostate cancer) prosztatarák; PI3K = (phosphatidylinositol 3-kinase) foszfatidilinozitol-3-kináz; PORCN = (porcupine) porcupin; PSA $=($ prostate specific antigen $)$ prosztataspecifikus antigén; PTEN = (phosphatase and tensin homolog) foszfatáz- és tenzinhomológ; RASSFlA = ras association domain family member $1 ; \mathrm{RB}=$ retinoblastoma; $\mathrm{RNF} 43$ = ring finger protein 43 ; $\mathrm{RSPO} 2=\mathrm{R}$-Spondin 2; SPOP = speckle-type $\mathrm{POZ}$ protein; TCGA $=$ The Cancer Genome Atlas; TMPRSS2 = (transmembrane protease, serine 2) transzmembrán szerin-proteáz-2; TP53 = tumorprotein p53; VX-970 $=($ ATR kinase inhibitor) ATR-kináz-inhibitor; ZBTB16 = zinc finger and BTB domain containing 16 ; ZNF154 = zinc finger protein 154 ; $\mathrm{ZNRF} 3$ = zinc and ring finger 3

A prosztatarák a fejlett világban a férfiak körében előforduló leggyakoribb daganattípus. Magyarországon évente mintegy 4500 új esetet diagnosztizálnak, míg az éves, prosztatarák miatti halálozás 1300 körül alakul [1]. A betegség klinikai és biológiai viselkedése meglehetősen heterogén. A lokális prosztatarák esetében a klinikailag veszélytelen, úgynevezett indolens tumorok agresszív daganatoktól történő elkülönítése jelent problémát. A túlkezelés megelőzése érdekében ezen indolens esetek kezelésének elkerülése kívánatos lenne, mivel azonban a korai, de agresszív prosztataráktól jelenleg nem különíthetők el biztonsággal, a kezelés a kockázat csökkentése érdekében gyakran megtörténik. Az elörehaladott, metasztatikus prosztatarákok kezdetben androgénmegvonással féken tarthatók, ám a szinte minden esetben kiala- kuló kasztrációrezisztencia megjelenésével ez a kezelés jellemzően egy-két év elteltével hatástalanná válik. Ebben a stádiumban a betegek kemoterápiában, új generációs hormonterápiákban, illetve egyedüli csontmetasztázis esetén alfa-sugárzó terápiában részesülhetnek, mely kezelésekre adott válasz tekintetében nagy egyéni különbségek figyelhetők meg. E feltünő klinikai heterogenitás a prosztatatumorok molekuláris hátterében rejló különbségekre vezethető vissza. A molekuláris vizsgálómódszerek fejlődésének köszönhetően sikerült mind a lokális, mind pedig a kasztrációrezisztens prosztatarákok teljes genetikai, epigenetikai, valamint transzkriptomikai hátterét feltérképezni. Ezen információk birtokában a prosztatarákok a genetikai eltéréseik alapján egymástól jól elkülöníthető molekuláris alcsoportokba sorolhatók. Ezenfelül ismertté váltak e tumorféleség kialakulásában és progressziójában szerepet játszó fóbb jelátviteli útvonalak is. Ezek közül mind a primer, mind pedig az előrehaladott prosztatarákban az androgénreceptor (AR)-, a PI3K-, a sejtciklust szabályozó és a WNT-jelátviteli útvonalak, valamint a DNS-hiba-javító mechanizmusok a leggyakrabban érintettek. Ezen új ismeretek nyomán megnyílt az út a prosztatarák kezelésének árnyaltabb, a tumor molekuláris sajátságait is figyelembe vevő terápiás algoritmusainak kialakítása, valamint az adott molekuláris eltérésekre tervezett célzott kezelések klinikai kipróbálása előtt. Az alábbiakban összefoglaljuk a prosztatarák főbb molekuláris sajátságait, különös tekintettel a terápiás szempontból lényeges eltérésekre és az ezekkel kapcsolatosan már engedélyezett és még kipróbálás alatt álló gyógyszerekre.

\section{A prosztatarák molekuláris alcsoportjai}

A prosztatarák molekuláris alcsoportjainak elkülönítése egymást kizáró genetikai és transzkriptomikai sajátságok alapján lehetséges.

A legnagyobb csoportot az ETS-géneket érintő fúziót hordozó prosztatarákok csoportja képviseli. A fennmaradó eseteket további három alcsoportba sorolhatjuk, melyek a SPOP-, a FOXAl - és az IDHl-gén mutációi alapján különíthetők el. Ezenkívül a legújabb vizsgálatok egy további alcsoport megkülönböztetését javasolják, mely a CDKl2-gén elvesztésével jellemezhető (1.ábra).

Az ETS egy transzkripciós faktorokat magában foglaló géncsalád, melynek tagja többek között az ERG, az ETV1, -4, -5, illetve az ELK4. Közülük az ERG a leggyakrabban sérült gén, melynek a TMPRSS2-génnel alkotott génfúziója a prosztatadaganatok körülbelül 50\%ában van jelen [2]. A TMPRSS2-ERG génfúzió a TMPRSS2-gén promóter régiójának és az ETS-nek a transzlokációjával jön létre, aminek következtében az ERG expressziója az androgénfüggő TMPRSS2-gén promóterének szabályozása alá kerül. Az ERG ennek hatására androgénszabályozás alá kerül, és nagyobb menynyiségben kezd el termelődni, ami egyes mátrixmetalloproteinázok és plazminogénaktivátor gének fokozott 


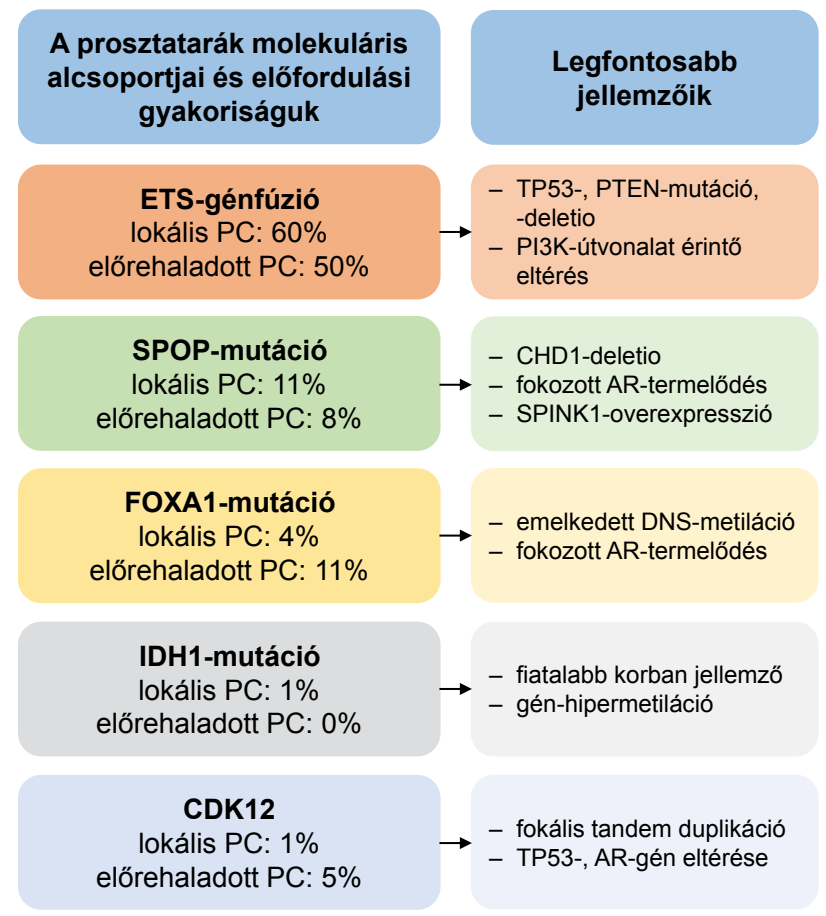

1. ábra

A prosztatarák 5 molekuláris alcsoportja és előfordulási gyakori-
ságuk primer és előrehaladott PC-ban, valamint a csoportok
legfontosabb sajátságai
$\begin{aligned} & \text { AR = androgénreceptor; DNS = dezoxiribonukleinsav; PC = } \\ & \text { prosztatarák }\end{aligned}$

képződéséhez és ezen keresztül a tumorsejtek fokozottan invazív növekedéséhez vezet [3]. Epigenetikai szempontból azonban az ERG-pozitív tumorok heterogén képet mutatnak; kétharmadukra mérsékelt DNS-metiláció, míg egyharmadukra hipermetiláció jellemző, mely az érintett gének csökkent kifejeződéséhez vezethet [4].

Az ETS-pozitív molekuláris altípusra jellemző további fontosabb elváltozások a TP53- és a PTEN-gént érintő mutációk és deletiók, valamint a PI3K-jelátviteli útvonalat érintő eltérések [4]. A különböző ETS-génátrendeződések prognosztikai jelentősége a rendelkezésre álló bőséges információ ellenére máig vitatott, és egyelőre terápiás célpontként sem használhatók [3].

A SPOP-génben létrejövő - jellemzően - pontmutációk mind primer, mind pedig metasztatikus prosztatarákban előfordulnak. A SPOP-gén a Cullin 3 E3 ubikvitinligáz enzim szubsztrátfelismerő régióját kódolja [5]. A SPOP-génmutációt hordozó tumorokban nem fordul elő az ETS-génátrendeződés, ugyanakkor erre a csoportra jellemző a CHDl-gén deletiója, az emelkedett DNSmetilációs profil, valamint az androgénreceptor fokozott termelődése [4, 6, 7]. Ezért az ehhez a csoporthoz sorolt daganatok valószínúleg jobban reagálnak az AR támadáspontú gyógyszerekre. A SPOP-génben előforduló mutációk klinikai jelentősége egyelőre vitatott. Egy nagy esetszámot felölelő tanulmány, amelyben primer és metasztatikus esetekből származó mintákat vizsgáltak, nem talált szignifikáns összefüggést a SPOP-gén mutációja és a betegek klinikopatológiai paraméterei között, ugyanakkor egy másik tanulmány szerint a SPOP-gén mutációja a rosszabb progressziómentes túléléssel áll összefüggésben $[7,8]$.

A FOXAl egy transzkripciós faktor, amely a primer prosztatarákoknak mintegy a 4\%-ában, a metasztatikus prosztatarákoknak pedig a 11\%-ában szenved mutációt $[4,9]$. Erre az alcsoportra a TCGA-vizsgálat alapján - a SPOP-mutációt hordozó tumorokhoz hasonlóan emelkedett DNS-metilációs profil, homogén génexpressziós mintázat, valamint nagyobb androgénreceptor-transzkripciós aktivitás jellemző [4].

Az izocitrát-dehidrogenáz-1 metabolikus enzimet kódoló IDHl-gén aktiváló mutációját hordozó esetek a primer prosztatarákok új, ritka csoportját képezik. Jellemzően fiatalabb betegek tumormintáiban fordul elő, és jellemző a gének hipermetilációja, míg szomatikus számbeli eltérések ebben a csoportban ritkábban fordulnak elő a többi alcsoporthoz képest [4].

A legújabb és egyik legkisebb molekuláris altípust a CDKI2 biallélikus inaktivációját hordozó prosztatadaganatok alkotják. Ezek a lokális prosztatarákok 1\%-át, míg a kasztrációrezisztens prosztatarákok $5 \%$-át teszik ki. A sérülés többnyire a gén kináz doménjét érinti, aminek következtében a CDK12-gén funkcióvesztést szenved, és ez egy jelenleg még ismeretlen mechanizmus által a genetikai eltérések egy sajátos mintázatának, az úgynevezett fokális tandem duplikációknak az egész genomot érintő elterjedéséhez vezet. A CDK12 sérülései az ETSfúzióval, illetve a SPOP-mutációkkal kölcsönösen kizárják egymást, ezért is indokolt külön alcsoportba sorolni őket. Ezzel szemben a TP53 és az AR eltérései előfordulnak CDK12-vesztés mellett is [10].

\section{A prosztatarákban leggyakrabban sérült jelátviteli útvonalak alapján történő besorolás}

\section{Androgénreceptor-jelátvitel}

A prosztatarák genetikai eltérései közül az androgénreceptor (AR)-jelpályát érintő eltérések mind lokális, mind pedig metasztatikus prosztatarákban jellemzők. Maga az AR azonban primer prosztatarákban csak ritkán mutat sérülést. Ezzel szemben az AR-t érintő pontmutációk és amplifikációk metasztatikus prosztatarákban gyakoriak, az esetek körülbelül 60\%-ában megtalálhatók $[4,9,11]$. Ugyanakkor az AR-jelpálya génjei (FOXAl, ZBTB16, NCORl, -2) mind a primer (4-11\%), mind a metasztatikus prosztatarákban (6-12\%) hordoznak a múködésüket befolyásoló mutációkat (2. ábra) $[4,6,11]$. A SPOPgén, amely ugyancsak része az androgén-jelátvitelnek, primer prosztatarákban gyakrabban mutat sérülést a metasztatikus esetekhez viszonyítva $[4,9]$. A mutációk és amplifikációk mellett a SPOP- és FOXAl-mutációt hordozó tumorokra jellemző a DNS hipermetilációja is, 


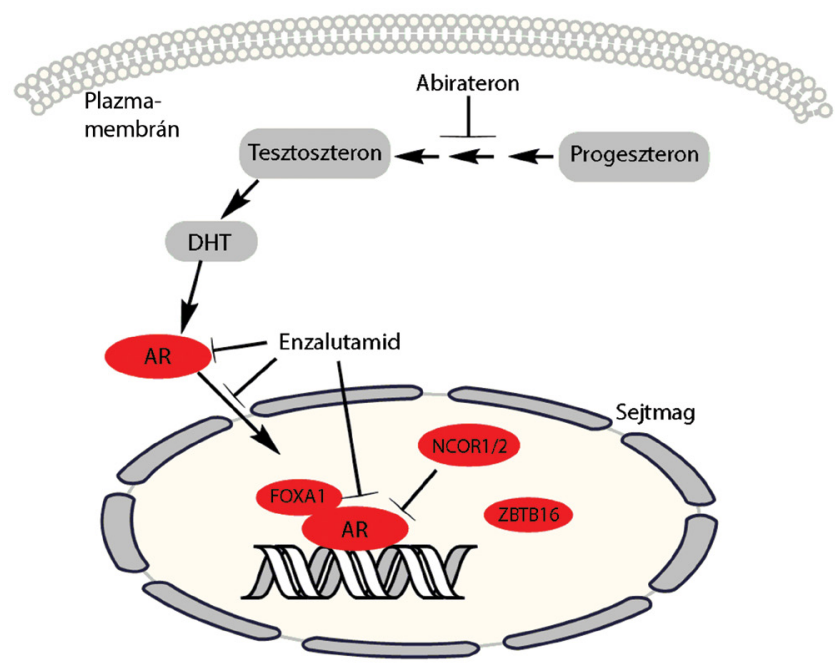

2. ábra

Fiziológiás körülmények között az AR ligandkötő doménjéhez bekötődő 5- $\alpha$-dihidrotesztoszteron (DHT) hatására a receptorkonformáció változáson megy keresztül, dimerizálódik, és a sejtmagba transzlokálódik, ahol a DNS-hez kötődve koaktivátorok jelenlétében az androgén által aktivált gének átíródását in dukálja. Prosztatarákban a leggyakrabban a pirossal jelölt gének eltérései fordulnak elő, melyeknek következménye az AR által fokozott génexpresszió

$\mathrm{AR}=$ androgénreceptor; DHT $=$ dihidrotesztoszteron; DNS = dezoxiribonukleinsav

mely a SPOP- és FOXAl-fehérjék csökkent termelődéséhez vezet [4].

$\mathrm{Az}$ AR-jelátviteli útvonal a leggyakoribb kezelési célpont a prosztataráknak mind a hormonérzékeny, mind a kasztrációrezisztens szakaszában. Az elmúlt néhány évben számos új androgén támadáspontú készítmény vált elérhetővé [12]. Az abirateron (Zytiga) egy specifikus CYP17Al-enzim-blokkoló, mely a sejtek androgénbioszintézisének gátlásán keresztül az endogén tesztoszteronszint csökkenését eredményezi többek között a tumorsejtekben is. 2011-ben az abirateron volt az első új generációs antiandrogén támadáspontú készítmény, melyet olyan, metasztatikus kasztrációrezisztens prosztatarákban (mCRPC) szenvedő betegek kezelésére törzskönyveztek, akik a docetaxelkemoterápia mellett vagy azt követően progrediáltak [13]. Ezt követően az AFFIRM-vizsgálat eredményei alapján 2012-ben engedélyezték az enzalutamid (Xtandi) alkalmazását olyan mCRPC-betegek részére, akiknél a docetaxelkezelés mellett vagy után a betegség progrediált. Az enzalutamid egy androgénreceptor-antagonista, mely hármas hatással rendelkezik: egyrészt kompetitív antagonistaként gátolja a receptor-ligand kötődés kialakulását, másrészt gátolja a receptor-ligand komplex sejtmagba jutását (nukleáris transzlokációját), valamint az AR DNS-hez való kötődését is [14]. Mindkét készítmény másodvonalban, docetaxel után alkalmazva Magyarországon is elérhető. Az abirateront 2012-ben a COU-AA-302-es vizsgálat alapján, az enzalutamidot pedig 2014-ben a PREVAIL-vizsgálat alapján törzskönyvezte az FDA kemoterápianaiv mCRPC-betegek kezelésére $[15,16]$.
Ebben az indikációban hazánkban jelenleg még csak egyedi méltányosság alapján érhető el. Az abirateron és az enzalutamid mellett számos, klinikai kipróbálás alatt álló készítmény van, amely az AR-jelátviteli útvonalon fejti ki hatását, ezeknek a részletes tárgyalása azonban meghaladná a jelen munka kereteit.

\section{A foszfatidilinozitol-3-kináz (PI3K)-szignálútvonal}

$\mathrm{Az}$ androgénjelpálya mellett a második leggyakrabban sérült jelátviteli út a PI3K-útvonal, mely aktiváló szerepet játszik a sejtosztódás, a túlélés, a metabolizmus és az angiogenezis szabályozásában, és így a tumor progressziójának irányába hat $[4,5]$. A PI3K-jelátviteli utat a protein-foszfatáz- és tenzinhomológ (PTEN) gátolja. Prosztatarákban az útvonal fokozott aktivitásának hátterében a PTEN hiánya áll, melynek következménye a fokozott sejtnövekedés, -proliferáció és gátolt apoptózis, ami végső soron a tumorprogresszió irányába hat (3. ábra). Ezzel összhangban a PTEN homozigóta deletiója a primer prosztatarákos betegek 15\%-ában, mutációja körülbelül a 2-4\%-ukban fordul elő $[4,5]$, míg a metasztatikus prosztatarákos betegeknek több mint a $40 \%$ ában található meg $[9,11]$. Kimutatták, hogy azon betegek túlélése, akik a PTEN-mutációt hordozzák, szignifikánsan rövidebb [17]. A PTEN-gén mellett a PIK3CA- és a PIK3CB-génben fordulnak elő a leggyak-

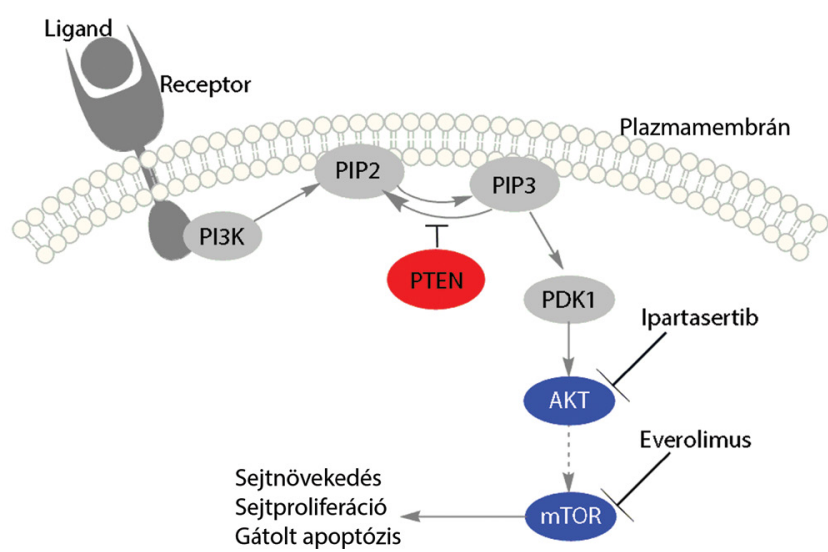

3. ábra A receptor ligandkötés hatására aktiválja a foszfaditilinozitol-
3-kinázt (PI3K), mely a foszfatidilinozitol-4,5-biszfoszfátot
(PIP2) foszfatidilinozitol-3,4,5-trifoszfáttá (PIP3) alakítja. A
foszforilációs kaszkád a PDK-, majd az AKT-fehérje aktivációjá-
val folytatódik, mely közvetetten aktiválja a tumorsejtek osztó-
dását és túlélését szabályozó mTOR-fehérjét. Az útvonal nega-
tív szabályozója a PTEN, mely a PIP3 defoszforilálásával gátolja
az AKT foszforilációját. Az útvonal magas aktivitásának hátteré-
ben a PTEN hiánya állhat, melynek következménye a fokozott
sejtnövekedés, -proliferáció és gátolt apoptózis. Prosztatarákban
a leggyakrabban patológiai eltérést szenvedett géneket pirossal,
a jelátviteli útvonal gyógyszeresen befolyásolható tagjait pedig
kékkel jelöltük
mTOR = emlős rapamicincélpont; PDK = foszfoinozitid-depen-
dens kináz; PI3K = foszfaditilinozitol-3-kináz; PIP2 = foszfati-
dilinozitol-4,5-biszfoszfát; PIP3 = foszfatidilinozitol-3,4,5-tri-
foszfát; PTEN = foszfatáz- és tenzinhomológ 
1. táblázat |A PI3K-szignálútvonalon, a sejtciklust szabályozó útvonalon és a WNT-útvonalon ható célzott terápiák klinikai vizsgálatai

\begin{tabular}{|c|c|c|c|c|c|c|}
\hline Útvonal & Név & Hatásmechanizmus & $\begin{array}{l}\text { Beválasztási betegcsoport/ } \\
\text { kritérium }\end{array}$ & Klinikai fázis & $\begin{array}{l}\text { Befejezés/ } \\
\text { Várható } \\
\text { befejezés }\end{array}$ & Klinikai vizsgálat \\
\hline \multirow{6}{*}{ 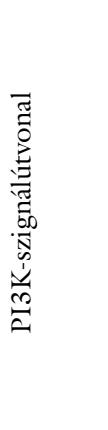 } & Everolimus & mTOR-inhibitor & kemonaiv CRPC & Fázis 2 & $2031 / 12$ & NCT00976755 \\
\hline & Everolimus + Docetaxel & mTOR-inhibitor & CRPC & Fázis 1 & $2012 / 12$ & NCT00459186 \\
\hline & Everolimus + Enzalutamid & $\begin{array}{l}\text { mTOR-inhibitor + } \\
\text { AR-antagonista }\end{array}$ & & $\begin{array}{l}\text { preklinikai } \\
\text { modell }\end{array}$ & & \\
\hline & GSK2636771 + Enzalutamid & $\begin{array}{l}\text { PI3K- } \beta \text {-inhibitor }+ \\
\text { AR-antagonista }\end{array}$ & mCRPC & Fázis 1 & $2020 / 05$ & NCT02215096 \\
\hline & Ipatasertib (GDC-0980) & AKT-inhibitor & & $\begin{array}{l}\text { preklinikai } \\
\text { modell }\end{array}$ & & \\
\hline & Ipatasertib + Abirateron & $\begin{array}{l}\text { AKT-inhibitor + CYP17- } \\
\text { inhibitor }\end{array}$ & $\begin{array}{l}\text { CRPC DOC-kezelés } \\
\text { után }\end{array}$ & Fázis 2 & $2018 / 06$ & NCT01485861 \\
\hline \multirow{7}{*}{ 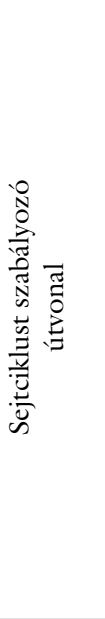 } & Prexasertib & CHKl-inhibitor & $\begin{array}{l}\text { előrehaladott szolid } \\
\text { tumor/HR-gén- } \\
\text { eltérés, MYC-amplifiká- } \\
\text { ció, RB-vesztés }\end{array}$ & Fázis 2 & $2021 / 09$ & NCT02873975 \\
\hline & Prexasertib + Olaparib & $\begin{array}{l}\text { CHKl-inhibitor + } \\
\text { PARP-inhibitor }\end{array}$ & $\begin{array}{l}\text { elörehaladott szolid } \\
\text { tumor }\end{array}$ & Fázis 1 & $2023 / 02$ & NCT03057145 \\
\hline & BAY1895344 & ATR-inhibitor & $\begin{array}{l}\text { elörehaladott szolid } \\
\text { tumor/CRPC }\end{array}$ & Fázis 1 & $2020 / 01$ & NCT03188965 \\
\hline & $\begin{array}{l}\text { VX-970 + Veliparib + } \\
\text { Ciszplatin }\end{array}$ & $\begin{array}{l}\text { ATR-inhibitor + PARP-in- } \\
\text { hibitor + Platina }\end{array}$ & $\begin{array}{l}\text { elörehaladott szolid } \\
\text { tumor }\end{array}$ & Fázis 1 & $2018 / 12$ & NCT02723864 \\
\hline & Ribociclib + Docetaxel & CDK4/6-inhibitor & $\mathrm{mCRPC}$ & Fázis 2 & $2019 / 12$ & NCT02494921 \\
\hline & Ribociclib + Enzalutamid & $\begin{array}{l}\text { CDK4/6-inhibitor + } \\
\text { AR-antagonista }\end{array}$ & $\begin{array}{l}\text { kemonaiv mCRPC/ } \\
\text { RB-pozitív }\end{array}$ & Fázis 2 & $2021 / 05$ & NCT02555189 \\
\hline & Palbociclib + ADT & CDK4/6-inhibitor & $\begin{array}{l}\text { hormonszenzitív } \\
\text { mPC/RB-pozitív }\end{array}$ & Fázis 2 & $2019 / 07$ & NCT02059213 \\
\hline \multirow{3}{*}{ 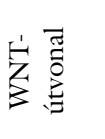 } & Foxy-5 & Wnt-inhibitor & $\mathrm{mPC}$ & Fázis 1 & $2017 / 06$ & NCT02655952 \\
\hline & Ipafricept & Wnt-inhibitor & szolid tumor & Fázis 1 & $2017 / 06$ & NCT01608867 \\
\hline & LGK974 & Porcupin-inhibitor & egyéb tumortípus & Fázis 1 & $2020 / 01$ & NCT01351103 \\
\hline
\end{tabular}

$\mathrm{CRPC}=$ kasztrációrezisztens prosztatarák DOC $=$ docetaxel $; \mathrm{mCRPC}=$ metasztatikus kasztrációrezisztens prosztatarák; $\mathrm{mPC}=$ metasztatikus prosztatarák

rabban mutációk, melyek fóleg a metasztatikus prosztatarákokra jellemzőek [5, 9]. A PIK3CA amplifikációja és egyes pontmutációi az útvonal túlzott aktivitását okozhatják. Mivel a PTEN- és a PIK3CA-gén ugyanazon jelút részei, nem meglepő, hogy genetikai eltéréseik kizárják egymást [18].

$\mathrm{Az}$ útvonal genetikai eltérései terápiás szempontból is jelentősek, tekintve, hogy jelenleg számos PI3K-, AKTés mTOR-inhibitor áll klinikai tesztelés alatt (1. táblá$z a t$ ). Ilyen molekula az mTOR-inhibitor everolimus, mely fázis 2 vizsgálatban jobb PSA-válasszal és hosszabb túléléssel korrelált azoknál a betegeknél, akik PTEN-deletiót hordoztak [19]. Továbbá az everolimus fázis 1 vizsgálatban docetaxellel kombinációban adva is biztonságosnak bizonyult [20]. Preklinikai vizsgálatban az everolimus enzalutamiddal kombinációban késleltette az enzalutamidrezisztencia kialakulását, és növelte az apoptózist [21]. Egy új PI3K- $\beta$-inhibitort, a GSK263677l-et fázis 1 klinikai vizsgálatban enzalutamiddal kombináció- ban tesztelnek (1. táblázat). Az ipatasertib pedig egy új AKT-inhibitor (GDC-0980), mely sejtmodelles vizsgálatban apoptózist indukált [22]. Az ipatasertibet jelenleg abirateronnal kombinálva fázis 2 vizsgálatban tesztelik docetaxelkezelésen átesett betegekben (1. táblázat). Az első eredmények biztatóak, hiszen az ipatasertib növelte a radiológiai progressziómentes és a teljes túlélést is olyan betegek esetében, akik PTEN-eltérést hordoztak [23].

\section{Sejtciklust szabályozó útvonal}

A sejtciklus szabályozó génjeinek sérülései mind primer, mind metasztatikus prosztatarákban előfordulnak (4. ábra). Míg primer prosztatarákban a TP53-gén körülbelül 8\%-ban, addig metasztatikus stádiumban már mintegy $50 \%$-ban sérültt $[4,5,9,11]$. A TP53-hibát hordozó sejtek terápiás célpontként történő támadása jelenleg kihívást jelent a klinikai gyakorlatban. Célzott terápiás sze- 


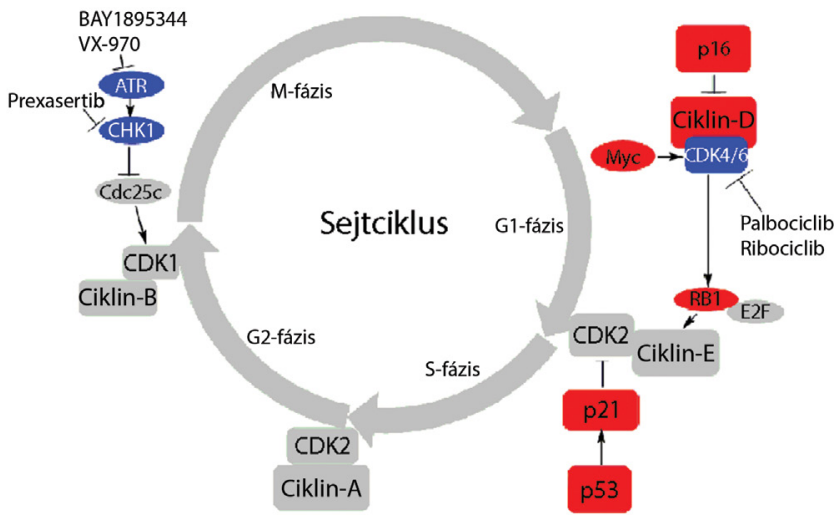

4. ábra A sejtciklus S-fázisba való átjutása előtt a ciklin-D a megfelelö
ciklindependens kinázzal (CDK4-6) komplexet alkot, mely ek-
kor foszforilálja és így gátolja a RB-fehérjét. Ez a folyamat fel-
szabadítja az elongációsfaktor-2 (E2F)-család azon célgénjeinek
expresszióját a gátlás alól, melyek termékei szükségesek a sejt-
ciklus S-fázisában a DNS-replikációhoz. Amennyiben a sejtet
valamilyen károsító hatás éri, a p53-as fehérje aktiválódik, és
felszabadítja a gátlás alól az általa aktivált molekulákat (p21), így
megakadályozva a G1/S ellenőrzési ponton való áthaladást,
amivel esélyt ad a hibák kijavítására, illetve apoptózist indukál-
hat. A sejtciklus szabályozásában részt vevó, a prosztatarák ki-
alakulásában leggyakrabban érintett géneket pirossal jelöltük,
patológiás eltéréseik a sejtciklus ellenőrzó pontjainak hibás mú-
ködéséhez vezetnek. A kékkel jelölt gének az útvonalon ható
célzott terápiák támadáspontjai
DNS = dezoxiribonukleinsav; RB = retinoblastoma

rekkel elsősorban a sejtciklus G2- és M-fázisa közötti átmenetet szabályozó gének, mint a CHKl és az ATR támadhatók, melyek érzékenyebbé teszik a P53-hibát hordozó sejteket a DNS-károsító ágensekkel szemben [24]. Jelenleg fázis 2 klinikai vizsgálatban tanulmányoznak egy $\mathrm{CHKl}$-inhibitort, a prexasertibet, amelynek alkalmazása olyan tumorok esetében lehet indokolt, amelyeknek a sejtciklusszabályzó génjeiben van eltérés (1. táblázat). A prexasertibet a közeljövőben klinikai fázis 1 vizsgálatban PARPl-inhibitorral (olaparib) kombinációban fogják tesztelni előrehaladott stádiumú szolid tumorok esetében. Az ATR-fehérje gátlására CRPC-ben a BAY1895344, míg különböző szolid tumorokban a VX-970 készítmények klinikai fázis 1 vizsgálat alatt állnak. Az utóbbi VX-970-et PARP-inhibitorral és ciszplatinnal kombinációban tesztelik (1. táblázat).

A RBl-gén sérülései mind primer, mind pedig metasztatikus prosztatarákban előfordulnak $[4,5,11]$. A RBfehérje foszforilálatlan formában gátolja a sejtciklus S-fázisához szükséges fehérjék/enzimek génjeinek aktiválódását; funkciójának kiesésekor ezen gének serkentése szabályozatlanul következik be. Állatkísérletekben a taxánkezelés a RBl funkcióvesztése esetén különösen hatásosnak bizonyult a normál, vad típusú RBl-et hordozó esetekhez képest [25].

A sejtciklus szabályozásában részt vevő ciklinek és ciklindependens kinázok is gyakran sérültek a prosztatarákban $[4,5,9]$. Jelenleg klinikai vizsgálatok folynak CDK4-6-inhibitorokkal, melyek hatékonyak lehetnek olyan tumorok esetében, amelyek hibás ciklindependens kinázokkal (CCNDl-amplifikáció vagy mutáns CDKN2A/B-gén) rendelkeznek (1. táblázat). Ilyen inhibitor a ribociclib, amelyet fázis 2 vizsgálatban mCRPC-betegekben docetaxel, illetve enzalutamidkezeléssel kombinálva tesztelnek (1. táblázat). Egy további CDK4-6-inhibitor a palbociclib, melyet fázis 2 vizsgálatban önmagában vagy androgénmegvonásos terápiával kombinációban tesztelnek (1. táblázat). Mind a ribociclib, mind pedig a palbociclib klinikai vizsgálatában beválasztási feltétel, hogy a RB vad típusú legyen.

Mind a primer, mind pedig a metasztatikus prosztatarák esetében előfordul a MYC-gén amplifikációja $[4,9]$. A MYC-gén a c-Myc-fehérjét kódolja, amely részt vesz a sejtciklus és a tumorgenezis szabályozásában [6]. A MYC-családba tartozik a L-MYC-gén is. Boutros és mtsai 74, klinikailag lokalizált, magas Gleason-pontszámú tumor vizsgálata során a minták 27\%-ában talált L-MYCamplifikációt, amely a TP53-gén deletiójával járt együtt [26]. Klinikai tesztelés alatt áll a fentebb említett prexasertib CHKl-inhibitor - ennek adása olyan tumorok esetében lehet indokolt, amelyeknek a sejtciklus szabályozásában és a homológ rekombinációban részt vevő génjeiben eltérést mutat (1. táblázat).

A sejtciklus szabályozásában részt vevő gének közül jellemzően a RASSFlA tumorszuppresszor gén, a NF154-gén és a ciklindependenskináz-inhibitor CDKN2A promóter régiója szenved metilációt prosztatarákban [4, 27]. Közülük a RASSFlA-gén metilációja prognosztikai markerként is szolgálhat [28], valamint a ZNF154-gén promóterének hipermetilációjáról mutatták ki, hogy az így létrejött funkcióvesztés összefüggésbe hozható a prosztatarák kialakulásával [29].

\section{WNT-útvonal}

A WNT-szignálútvonalat érintő eltérések fooleg a metasztatikus prosztatarákra jellemzőek, melyekben körülbelül 18\%-ban sérül ez az útvonal [9]. A WNT-szignálút számos fiziológiás folyamatban vesz részt, úgymint az embrionális fejlődés és a homeosztázis fenntartása. Az útvonal két leggyakrabban sérült génje a CCTNBI és az APC (5. ábra) [9]. Diagnosztikai szempontból fontos az APC-gén promóter régiójának metilációja. Ez az epigenetikai elváltozás már a prosztatarák korai szakaszában kimutatható, így felmerült, hogy vizsgálata segíthet a betegség korai kimutatásában [30]. Emellett Robinson és mtsai 150 CRPC-beteg tumormintáinak vizsgálata során a RNF43-, a ZNRF3- és a RSPO2-génben is találtak eltéréseket, mely gének mutációit korábban vastagbél-, endometrialis és adrenocorticalis daganatokban azonosították [9]. Továbbá a Wnt-molekula egyik célgénjének, a CD24-glikoproteinnek az expressziója prosztatarákban jelentős emelkedést mutat [31], ezért felmerült, hogy a CD24-gén ellen termelt ellananyaghoz gyógyszermolekulákat kapcsolva a prosztataráksejtek szelektíven elpusztíthatók. Újabb állatkísérletes kutatások kimutatták, hogy a nanopartikulába csomagolt, anti-CD24-hez kap- 


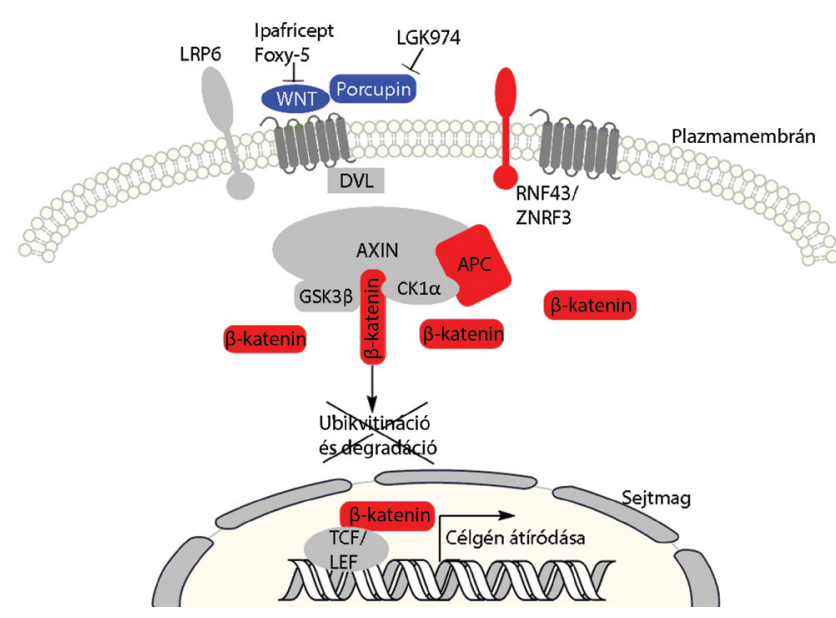

5. ábra

\begin{abstract}
Wnt-molekula hiányában a glikogén-szintáz-kináz-3 $\beta$ (GSK3 $\beta$ ) az APC-molekulával és az axin fehérjével foszforilálja a citoplazmában található $\beta$-katenin-molekulát, mely ezáltal ubikvitinálódik, majd a proteoszómában lebomlik. Wnt-molekula jelenlétében a Dvl-komplex aktiválódik, és foszforilálja GSK3 $\beta$-APC-axin komplexet, aminek hatására a $\beta$-katenin a magba vándorol, és a transzkripcióban vesz részt. Az útvonal két leggyakrabban patológiai eltérést szenvedő fehérjéje az APC és a $\beta$-katenin (pirossal jelölt molekulák). Mindkét fehérje sérülésének hatására a szolúbilis $\beta$-katenin szintje megnő a sejtben, ami a sejtmagba transzlokálódva a célgének átíródását indukálja. Az ábrán kékkel jelöltük az útvonalon ható célzott terápiák támadáspontját

$\mathrm{APC}=$ adenomatosus polyposis coli
\end{abstract}

csolt docetaxel hatékonyabb a szimplán nanopartikulába csomagolt docetaxelhez képest [32].

A WNT-útvonal génjeiben mutációt hordozó betegek kezelésére használt gátlószereket a 1 . táblázat tartalmazza. Jelenleg klinikai fázis 1 vizsgálat alatt áll a foxy-5 nevű molekula, amely a Wnt5a hatását utánozva legyengíti az epitheleredetű tumorsejtek migrációját, ezáltal antimetasztatikus hatást ér el. Az LGK974 olyan porcupininhibitor, mely a PORCN-gén gátlásán keresztül szabályozza a WNT-útvonalat; a klinikai vizsgálat beválasztási kritériuma, hogy a betegeknek ismert genetikai eltérésük legyen ezen a jelútvonalon. Az ipafricept (OMP-54F28) egy rekombináns fúziós fehérje, mely képes a Wnt-ligandhoz kötődni és ezáltal a WNT-jelútvonalat gátolni [33].

\section{DNS-hiba-javitó mechanizmus}

A környezeti tényezők által okozott mutációk, valamint a sejtosztódást megelőző DNS-megkettőződés során létrejövő másolási hibák különböző típusainak kijavítására a szervezetben különböző hibajavító mechanizmusok léteznek. Ha a sérülés csak a DNS egyik szálát érinti, amely lehet egyszálú törés vagy báziseltérés, akkor ezek javítása egyszálútörés-javítással történik, amelyben a bázisexcíziós (BER), nukleotidexcíziós (NER) vagy mismatch repair (MMR) mechanizmusok vehetnek részt. A DNS kétszálú töréseinek kijavítása pedig úgynevezett homológrekombinációval, illetve a nem homológ végek illesztésével lehetséges. Ha azonban a hibajavító rendszernek nem sikerül kijavítani a hibát, és a sejt életben marad, a genom instabillá válik, ami a tumorok kialakulásának kedvez [34]. Az olyan tumorokban, amelyekben a DNS-hiba-javító rendszerben részt vevő fehérjék génjei sérültek, és ezért múködésük csökkent vagy gátolt, a mutációk az egész genomban látványos módon felszaporodnak, létrejön az úgynevezett hipermutáns fenotípusú tumor. A hipermutáns daganatok a többi daganathoz képest sokszorosan több mutációt tartalmaznak.

A DNS-hiba-javító rendszer génjeinek sérülései mind a primer, mind a metasztatikus prosztatarákokra jellemzőek. A lokális prosztatarákok körülbelül 19\%-ában található meg germinális vagy szomatikus eltérés a DNS-hiba-javító mechanizmus valamelyik génjében, míg a metasztatikus minták esetében ez az eltérés 23\% [4, 9].

A homológrekombinációban részt vevő legfontosabb gének a BRCA2, az ATM, a FANCD2 és a RAD51C. Közülük onkológiai szempontból a BRCA2 és az ATM hibái emelhetők ki. A BRCA2 eltérései a metasztatikus prosztatarákok mintegy 12\%-ában fordulnak elő, ezek körülbelül 9\%-a mutáció, 3\%-a pedig biallélikus vesztés [9]. Egy nagy esetszámú tanulmány $(\mathrm{n}=692)$ a metasztatikus prosztatarákos betegek 12\%-ában talált germinális mutációt a DNS-hiba-javító mechanizmus valamelyik génjében. A leggyakrabban sérült gének a BRCA2 (37 beteg $[5,3 \%])$, az ATM (11 [1,6\%]) és a CHEK2 (10 [1,9\%]) voltak [35]. A homológrekombinációban részt vevő gének mutációi között fontos megemlíteni a glutation-S-transzferáz-Pl (GSTPl)-gén hipermetilációját, mely a leggyakoribb epigenetikai elváltozás prosztatarákban. A metiláció a gén CpG-ben gazdag promóter régióját érinti, ami ezáltal a gén csökkent expressziójához vezethet $[4,30]$.

A poli(ADP-ribóz)-polimeráz (PARP)-inhibitorokkal kedvező terápiás hatást lehet elérni azon betegek esetében, akikben a BRCA2 - vagy egyéb, a homológrekombinációban szerepet játszó gén mutációt tartalmaz. Ez a terápiás stratégia az úgynevezett szintetikus letalitás jelenségét használja ki. A szintetikus letalitás két gén közötti kapcsolatot jelent, amelyben ha az egyik gén hibás, de a másik gén ép, akkor a sejt még életképes maradhat, viszont mindkét gén érintettsége a sejt halálát okozza. Amikor a DNS-molekulában egyszálú törés keletkezik, akkor a PARP-komplex a törött DNS-szálhoz kötődik, és elindítja a hibajavítást. A PARP-komplex gátlásával azonban a DNS-hiba-javítás elmarad, és a DNS-ben kétszálú törés keletkezik, amelyet a homológrekombinációs hibajavító mechanizmus hivatott kijavítani. Amennyiben ez utóbbi sérült, akkor a kettős szálú DNS-törés javíthatatlanná válik, és a sejt elpusztul. Ennek a terápiás stratégiának a lényege tehát, hogy a PARP-inhibitorok a szintetikus letalitás folyamatán keresztül a homológrekombináció génjeiben hibás tumorsejtek célzott halálát okozzák [34]. Ezen a mechanizmuson keresztül fejti ki hatását a PARP-gátló olaparib, amelyet fázis 2 klinikai vizsgálatban 50 metasztatikus prosztatarákos betegen 
vizsgáltak. Összesen 16 beteg esetében figyeltek meg terápiás választ, közülük 14 (88\%) tartalmazott BRCA2-, illetve ATM-mutációkat [36]. Az olaparib hatékonyságát vizsgálják radikális prosztatamútéten átesett, magas kockázatú, biokémiai progressziót mutató betegek esetében, illetve mCRPC-betegeknél abirateronnal kombinálva is (2. táblázat). Ez utóbbi vizsgálat első eredményei alapján azoknál a betegeknél, akik kombinációban kapták a kezelést, szignifikánsan hosszabb volt a radiológiai progresszióig eltelt idő azokhoz a betegekhez képest, akik csak abirateronkezelést kaptak. A vizsgálathoz a betegek homológrekombinációban részt vevő génjeinek mutációit is megvizsgálták. A beválasztott 142 beteg közül 21 beteg esetében találtak ezekben a génekben mutációt. Az eredmények alapján meglepó módon a PARPinhibitor hatékonysága független volt a tumor homológ- rekombinációs génjeinek mutációs statusától [37]. További klinikai vizsgálatok folynak újabb PARP-inhibitorokkal, mint a velaparib, a niraparib, a rucaparib és a talazoparib. A niraparib kombinált PARP1- és PARP2inhibitor, amely sejtmodellvizsgálat alapján gátolta a PTEN és BRCA2 mutáns tumorok növekedését [38]. Az első klinikai vizsgálat azonban nem talált összefüggést a csökkent PTEN-expresszió, az ERG-átrendeződés és a niraparib tumorellenes hatása között [39]. Jelenleg a niraparib hatását fázis 2 vizsgálatban tesztelik mCRPCbetegekben (2. táblázat). Továbbá a niraparibkészítményt egy további fázis $1 \mathrm{~b} / 2$ vizsgálatban $\mathrm{PD}-1$ monoklonális antitesttel kombinálva tesztelik mCRPC-betegeknél. Klinikai fázis 1 vizsgálatban a velaparibot temozolomiddal kombinációban adva a betegek jól tolerálták, de tumorellenes hatása mérsékelt volt [40].

2. táblázat |A DNS-hiba-javító mechanizmus sérülései esetén alkalmazható szerek klinikai vizsgálatai

\begin{tabular}{|c|c|c|c|c|c|c|}
\hline Név & Hatásmechanizmus & Betegcsoport & Study elnevezése & Klinikai fázis & $\begin{array}{l}\text { Befejezés/ } \\
\text { Várható } \\
\text { befejezés }\end{array}$ & Klinikai vizsgálat \\
\hline Olaparib & PARPl-inhibitor & mCRPC & TOPARP & Fázis 2 & 2016 & NCT01682772 \\
\hline Olaparib & PARPl-inhibitor & nem metasztatikus PC & & Fázis 2 & $2022 / 03$ & NCT03047135 \\
\hline Olaparib + Abirateron & $\begin{array}{l}\text { PARPl-inhibitor + } \\
\text { CYP17-inhibitor }\end{array}$ & $\mathrm{mCRPC}$ & & Fázis 2 & $2018 / 12$ & NCT01972217 \\
\hline Niraparib & PARPl-inhibitor & $\begin{array}{l}\text { lokálisan előrehaladott } \\
\text { vagy mPC }\end{array}$ & & Fázis 1 & $2013 / 06$ & NCT00749502 \\
\hline Niraparib & PARPl-inhibitor & $\begin{array}{l}\text { mCRPC + DNS-repair } \\
\text { gén eltérése }\end{array}$ & Galahad & Fázis 2 & $2020 / 02$ & NCT02854436 \\
\hline Niraparib & $\begin{array}{l}\text { PARP1 + PD-1 monoklo- } \\
\text { nális antitest }\end{array}$ & $\mathrm{mCRPC}$ & & Fázis $1 b / 2$ & $2020 / 12$ & NCT03431350 \\
\hline Velaparib & PARPl-inhibitor & $\mathrm{mCRPC}$ & & Fázis 1 & 2011 & NCT01085422 \\
\hline Velaparib + Abirateron & $\begin{array}{l}\text { PARPl-inhibitor + } \\
\text { CYP17-inhibitor }\end{array}$ & $\mathrm{mCRPC}$ & & Fázis 2 & $2018 / 12$ & NCT01576172 \\
\hline Rucaparib & PARP-inhibitor & $\mathrm{mCRPC}$ & TRITON2 & Fázis 2 & $2020 / 04$ & NCT02952534 \\
\hline Rucaparib & PARP-inhibitor & $\mathrm{mCRPC}$ & TRITON3 & Fázis 3 & $2022 / 04$ & NCT02975934 \\
\hline Rucaparib & PARP-inhibitor & hormonszenzitív mPC & TRIUMPH & Fázis 2 & $2021 / 11$ & NCT03413995 \\
\hline Talazoparib & PARP-inhibitor & $\begin{array}{l}\text { mCRPC + DNS-repair } \\
\text { gén eltérése }\end{array}$ & Talapro-1 & Fázis 2 & $2022 / 03$ & NCT03148795 \\
\hline $\begin{array}{l}\text { Talazoparib + Enzaluta- } \\
\text { mid }\end{array}$ & $\begin{array}{l}\text { PARP-inhibitor + } \\
\text { AR-antagonista }\end{array}$ & $\begin{array}{l}\text { mCRPC + DNS-repair } \\
\text { gén eltérése }\end{array}$ & & Fázis 3 & $2024 / 03$ & NCT03395197 \\
\hline Ipilimumab & $\begin{array}{l}\text { anti-CTLA4 monoklonális } \\
\text { antitest }\end{array}$ & kemonaiv mCRPC & & Fázis 3 & $2015 / 07$ & NCT01057810 \\
\hline Ipilimumab & $\begin{array}{l}\text { anti-CTLA4 monoklonális } \\
\text { antitest }\end{array}$ & $\begin{array}{l}\text { mCRPC DOC-kezelés } \\
\text { után }\end{array}$ & & Fázis 3 & $2015 / 08$ & NCT00861614 \\
\hline $\begin{array}{l}\text { Ipilimumab + Abirate- } \\
\text { ron }\end{array}$ & $\begin{array}{l}\text { monoklonális antitest }+ \\
\text { CYP17-inhibitor }\end{array}$ & $\begin{array}{l}\text { kemo- és immunnaiv } \\
\text { mCRPC }\end{array}$ & & Fázis 2 & $2018 / 09$ & NCT01688492 \\
\hline Pembrolizumab & $\begin{array}{l}\text { anti-PD-1 monoklonális } \\
\text { antitest }\end{array}$ & $\begin{array}{l}\text { elörehaladott szolid } \\
\text { tumor }\end{array}$ & KEYNOTE-28 & Fázis 1 & $2018 / 09$ & NCT02054806 \\
\hline $\begin{array}{l}\text { Atezolizumab + } \\
\text { Enzalutamid }\end{array}$ & $\begin{array}{l}\text { anti-PD-Ll monoklonális } \\
\text { antitest }\end{array}$ & $\mathrm{mCRPC}$ & IMbassador250 & Fázis 3 & $2022 / 07$ & NCT03016312 \\
\hline
\end{tabular}

$\mathrm{mCRPC}=$ metasztatikus kasztrációrezisztens prosztatarák; $\mathrm{mPC}=$ metasztatikus prosztatarák 
Jelenleg a velaparib abirateronkezeléssel kombinációban fázis 2 klinikai vizsgálat alatt áll (2. táblázat). Az első eredmények alapján azok a betegek, akiknek a DNS-hiba-javító génjei (BRCA1, BRCA2, ATM, FANCA, PALB2, RAD51B, RAD51C) sérültek voltak, szignifikánsan jobban reagáltak a kezelésre, mint azok a betegek, akiknek vad típusú tumoruk volt [41]. Ugyanebben a vizsgálatban az ETS-génátrendeződés nem volt hatással a velaparibkezelés hatékonyságára [41]. A rucaparib hatékonyságát jelenleg egyszerre több betegcsoporton (homológrekombinációban szerepet játszó géneltéréssel rendelkező mCRPC-, illetve metasztatikushormonszenzitív betegeken) is vizsgálják. A talazoparib szintén egy újabb PARP-inhibitor, amelyet mCRPC-betegek kezelésére önmagában alkalmazva és enzalutamiddal kombinációban is vizsgálnak (2. táblázat).

A PARP-inhibitorok mellett platinaalapú kemoterápiával is kedvező hatást lehet elérni olyan metasztatikus prosztatarákos betegek kezelésében, akik BRCA2-mutációt hordoznak. Egy kis létszámú esettanulmány alapján azok a betegek, akiknek a tumormintái BRCA2 biallélikus vesztést hordoztak, a standard docetaxellel és az új generációs készítményekkel (enzalutamid, abirateron) való kezelés alatt progrediáltak, viszont az ezt követő karboplatin/ciszplatin terápiára érzékenyen reagáltak [42]. Egy másik, 141, karboplatinnal kezelt beteg adatait feldolgozó tanulmányban a 8 , patogén csírasejtes BRCA2-mutációt hordozó beteg közül 6 mutatott legalább 50\%-os PSA-csökkenést, míg ugyanez az arány a 133, BRCA2-t nem hordozó beteg esetében csupán 17\% $(23 / 133)$ volt [43].

A prosztatarákban ritkán előfordulnak a mismatch repair (MMR-) gének hibái is, melyek közül az MLHl és az MSH2 sérülései a leggyakoribbak. Az MMR-sérülést hordozó PC-betegek életkilátásai kedvezőtlenebbek az MMR-sérülést nem hordozó betegekhez képest [44]. A gátolt MMR-rendszer következtében úgynevezett mikroszatellitainstabilitás (MSI) jön létre, mely e sérülések molekuláris markereként is használható. A mutációk felszaporodása következtében a hibás, immunogén fehérjék száma megnövekszik a tumorban, ami erőteljesebb Tsejt-beszürődéshez vezet. Ismert, hogy az ilyen „immunogén" tumorokban az 'immun checkpoint inhibitor' kezelések hatékonysága magasabb. Az 'immun checkpoint' kezelések a tumorsejtek T-lymphocytákra gyakorolt gátló hatásának blokkolásán keresztül fejtik ki hatásukat. Ez a hatás a tumorsejtek felszínén jelen lévő ligandfehérjékkel (mint a PD-1) kapcsolatos, melyek a T-lymphocyták felszínén jelen lévő gátló hatású receptorokat (mint a PD-L1) képesek aktiválni. Az 'immun checkpoint' kezelés ezt a gátló hatást képes felfüggeszteni, és így a gátlás gátlásán keresztül a tumorellenes immunválasz képes lesz kifejlődni és elpusztítani a tumorsejteket. A kezelés fóként olyan betegek esetében hatékony, akiknek a tumorában eröteljes T-sejt-beszürődés figyelhető meg már a kezelés megkezdése előtt. A sérült MMR-rendszerrel rendelkező MSI-tumorok fo- kozott immunogenitást mutatnak, és ezért jellemzően jobban reagálnak a 'checkpoint inhibitor' kezelésre. Az ipilimumab egy humán monoklonális antitest, mely képes a citotoxikus T-lymphocyta-antigénhez kötődni s ezáltal erősíteni az immunválaszt. Klinikai vizsgálatok során minimális hatást értek el az ipilimumab tesztelése során, kemoterápianaiv és docetaxelkezelésen átesett betegeknél $[45,46]$. Emellett számos, ipilimumabbal kapcsolatos vizsgálat van klinikai tesztelés alatt, többek között abirateronkezeléssel kombinálva (2. táblázat). Egy további immunterápiás szer az anti-PD-1 monoklonális antitest pembrolizumab, amelynek klinikai tesztelése metasztatikus prosztatarákos betegek esetében folyamatban van. A pembrolizumab fázis 1 vizsgálatába több mint 200, különböző tumorféleségben szenvedő beteget vontak be. A prosztatarákos betegek 17,4\%-ánál értek el részleges választ, míg további 34,8\%-nál nem tapasztaltak változást a betegek állapotában [47]. Az atezolizumab egy anti-PD-Ll monoklonális antitest, melyet egy közeljövőben induló fázis 3 klinikai vizsgálatban enzalutamiddal kombinációban fognak tesztelni (2. táblázat).

Egy friss megfigyelés szerint a ciklindependens kináz-12 (CDK12) biallélikus elvesztése a prosztatarákok új molekuláris alcsoportját képviseli. A CDK12 funkcióvesztésének következtében a mutációk száma jelentősen megnő. Ennek hátterében korábban a CDKl2-gén a homológrekombinációs hibajavító mechanizmusban részt vevő gének (BRCAl, ATR, FANCJ, FANCD2) transzkripciójára gyakorolt aktiváló hatását gyanították. Egy újabb tanulmány azonban nem talált összefüggést a CDK12 elvesztése és a fenti gének expresziója között. Megfigyelték azonban, hogy a CDKl2-hibát hordozó prosztatarákos betegek egy genomszinten is megfigyelhető jellegzetes mutációs mintázatot, az úgynevezett fokális tandem duplikációt hordozzák. Ez a mintázat csekély mértékü amplifikációval (duplikációval) jellemezhető, mely gyakran egymáshoz közeli gének fúzióját okozza. Ezen fúziós fehérjék között gyakoriak azok a neoantigének, melyek gyakran fokozott immunválaszt váltanak ki. Ismert, hogy a neoantigének emelkedett mennyisége a tumorok fokozott T-sejt-beszűrődésével és a checkpointgátló kezelésekkel szemben mutatott nagyobb érzékenységgel jár együtt. Ezért a CDKl2-deficiens betegek várhatóan kedvező terápiás választ adnak az immunkezelésekre [10]. A prosztatarák mellett a CDK12-mutációt számos egyéb tumortípusban (emlő-, méhnyak-, petefészek-, vastagbél-, tüdő-, gyomor- és nyelőcsődaganat) leírták, és új terápiás célpontnak tekintik [48]. További vizsgálatok azt mutatták, hogy azok a sejtek, amelyeknek a CDK12-génje hibás volt, érzékenyebben reagáltak a PARP-inhibitor-kezelésre [49]. Ezek alapján a CDK12-allél-vesztést hordozó betegek mind a PARP-inhibitor-, mind pedig a checkpointinhibitor-kezelésre pozitívan reagálhatnak. 


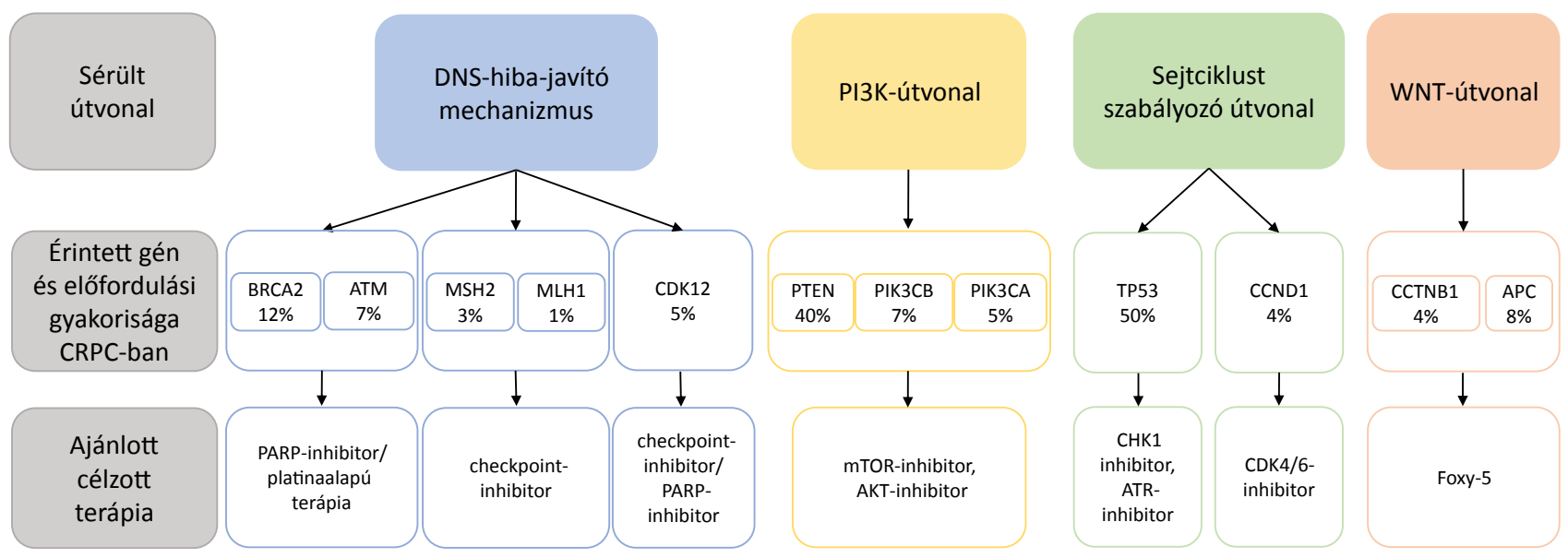
$\mid \begin{aligned} & \text { A metasztatikus prosztatarákban leggyakrabban előforduló genetikai eltérések és célzott terápiás lehetőségeik }[6,9,10,11] \\ & \text { CRPC = kasztrációrezisztens prosztatarák; DNS = dezoxiribonukleinsav; PARP = poli(ADP-ribóz) polimeráz }\end{aligned}$

\section{A kromatinszerkezetet befolyásoló molekulák}

A hisztonok módosításában részt vevő fehérjék génjeinek eltérései is előfordulnak a prosztatarákban. Ezek a fehérjék fontos szerepet játszanak a DNS-hiba-javítás és a genomi integritás fenntartásában [5]. Míg a KMT2Cés a KMT2D-gén mutációi a primer prosztataráknak csupán a 2-3\%-ában találhatók meg, addig az előrehaladott stádiumban már $12-14 \%$ ez az arány $[4,9,11]$. A KMT2D- és a KMT2C-gén részt vesz a H3-as hisztonalegység 4. pozíciójában lévő lizin (H3K4) metilálásában, mely ezáltal közvetett módon a transzkripció szabályozásában vesz részt. A CHDl-gén a kromodomén-helikáz DNS-kötő fehérjét kódolja, mely részt vesz a kromatin szerkezetének helyreállításában. A gén deletiója mind primer, mind pedig metasztatikus prosztatarákban előfordul $[4,9,11]$. Terápiás célpontként jelenleg nem használhatók, de sejtmodelles vizsgálat alapján a CHDI mutáns sejtek érzékenyebben reagáltak a PARP-inhibitorokra [50].

\section{Következtetések}

A molekuláris biológiai módszerek fejlődésénék köszönhetően eddig még soha nem látott mélységű betekintést nyerhettünk mind a korai stádiumú, mind pedig a kasztrációrezisztens prosztatarákok molekuláris alapjaiba. Ezen ismeret birtokában sikerült a prosztatarákot az előforduló genetikai eltérések alapján alcsoportokba sorolni, valamint ismertté váltak e tumorféleség kialakulásáért és progressziójáért felelős legfőbb jelátviteli útvonalak. A leggyakrabban érintett szignálutak azonosításával egyre növekvő számban kerülnek tesztelésre olyan, többnyire célzott terápiás szerek, melyek indikációja az adott tumor molekuláris eltéréseihez igazodik. Ezért a közeljövőben várhatóan már a tumor molekuláris sajátságai is bekerülhetnek a klinikai döntéshozatalba, aminek segít- ségével árnyaltabb, az adott tumor biológiai viselkedését is tekintetbe vevő és ezáltal hatékonyabb kezelési sémák dolgozhatók ki. A jelenlegi ismeretek birtokában felvázoltuk, hogy mely genetikai eltérések mely terápia hatékonyságát vetítik elöre (6. ábra). Az ezen a területen zajló meglehetősen aktív molekuláris és klinikai kutatások egymást kiegészítve segítik újabb szerek kifejlesztését, ami előrevetíti a terápiás választási lehetőségek gyorsuló ütemú bővülését.

Anyagi támogatás: A cikk a NKFIH (FK 12443), a NVKP (16-1-2016-004) és a Bolyai János Kutatási Ösztöndíj támogatásával készült.

Szerzői munkamegosztás: Sz. T.: A téma felvetése, a kézirat megírása, a kézirat javítása. Cs. A.: Irodalomkutatás, a kézirat megírása, összeállítása, a táblázatok szerkesztése, az ábrák megrajzolása. Sz. M., Ny. P.: A kézirat lektorálása. A cikk végleges változatát valamennyi szerző elolvasta és jóváhagyta.

Érdekeltségek: A szerzőknek nincsenek érdekeltségeik.

\section{Irodalom}

[1] Kásler M, Ottó Sz, Kenessey I. The current situation of cancer morbidity and mortality in the light of the National Cancer Registry, Hungary. [A rákmorbiditás és -mortalitás jelenlegi helyzete a Nemzeti Rákregiszter tükrében.] Orv Hetil. 2017; 158: 8489. [Hungarian]

[2] Paulo P, Barros-Silva JD, Ribeiro FR, et al. FLIl is a novel ETS transcription factor involved in gene fusions in prostate cancer. Genes Chromosomes Cancer 2012; 51: 240-249.

[3] Acs B, Szarvas T, Szekely N, et al. Current state of ERG as biomarker in prostatic adenocarcinoma. Curr Cancer Drug Targets 2015; 15: 643-651.

[4] Cancer Genome Atlas Research Network. The molecular taxonomy of primary prostate cancer. Cell 2015; 163: 1011-1025. 
[5] Barbieri CE, Bangma CH, Bjartell A, et al. The mutational landscape of prostate cancer. Eur Urol. 2013; 64: 567-576.

[6] Barbieri CE, Baca SC, Lawrence MS, et al. Exome sequencing identifies recurrent SPOP, FOXAl and MED12 mutations in prostate cancer. Nat Genet. 2012; 44: 685-689.

[7] Blattner M, Lee DJ, O'Reilly C, et al. SPOP mutations in prostate cancer across demographically diverse patient cohorts. Neoplasia 2014; 16: 14-20.

[8] Garcia-Flores M, Casanova-Salas I, Rubio-Briones J, et al. Clinico-pathological significance of the molecular alterations of the SPOP gene in prostate cancer. Eur J Cancer 2014; 50: 2994 3002.

[9] Robinson D, Van Allen EM, Wu Y-M, et al. Integrative clinical genomics of advanced prostate cancer. Cell $2015 ; 161$ : 12151228.

[10] Wu YM, Cieślik M, Lonigro RJ, et al. Inactivation of CDKl2 delineates a distinct immunogenic class of advanced prostate cancer. Cell 2018; 173: 1770-1782.el4.

[11] Grasso CS, Wu YM, Robinson DR, et al. The mutational landscape of lethal castration-resistant prostate cancer. Nature 2012; 487: 239-243.

[12] Küronya Zs, Bíró K, Gyergyai F, et al. Androgen receptor-mediated processes in castrate-resistant metastatic prostate cancer. [Androgénreceptor mediálta folyamatok metasztatikus kasztrációrezisztens prosztatadaganatban.] Orv Hetil. 2017; 158 : 42-49. [Hungarian]

[13] de Bono JS, Logothetis CJ, Molina A, et al. Abiraterone and increased survival in metastatic prostate cancer. N Engl J Med. 2011; 364: 1995-2005.

[14] Scher HI, Fizazi K, Saad F, et al. Increased survival with enzalutamide in prostate cancer after chemotherapy. $\mathrm{N}$ Engl $\mathrm{J}$ Med. 2012; 367: 1187-1197.

[15] Ryan CJ, Smith MR, de Bono JS, et al. Abiraterone in metastatic prostate cancer without previous chemotherapy. N Engl J Med. 2013; 368: 138-148.

[16] Loriot Y, Miller K, Sternberg CN, et al. Effect of enzalutamide on health-related quality of life, pain, and skeletal-related events in asymptomatic and minimally symptomatic, chemotherapynaive patients with metastatic castration-resistant prostate cancer (PREVAIL): results from a randomised, phase 3 trial. Lancet Oncol. 2015; 16: 509-521.

[17] Ferraldeschi R, Nava Rodrigues D, Riisnaes R, et al. PTEN protein loss and clinical outcome from castration-resistant prostate cancer treated with abiraterone acetate. Eur Urol. 2015; 67: 795-802.

[18] Sun X, Huang J, Homma T, et al. Genetic alterations in the PI3K pathway in prostate cancer. Anticancer Res. 2009; 29: 17391743.

[19] Templeton AJ, Dutoit V, Cathomas R, et al. Phase 2 trial of single-agent everolimus in chemotherapy-naive patients with castration-resistant prostate cancer (SAKK 08/08). Eur Urol. 2013; 64: 150-158

[20] Courtney KD, Manola JB, Elfiky AA, et al. A phase I study of everolimus and docetaxel in patients with castration-resistant prostate cancer. Clin Genitourin Cancer 2015; 13: 113-123.

[21] Toren P, Kim S, Cordonnier T, et al. Combination AZD5363 with enzalutamide significantly delays enzalutamide-resistant prostate cancer in preclinical models. Eur Urol. 2015; 67: 986990.

[22] Wallin JJ, Edgar KA, Guan J, et al. GDC-0980 is a novel class I $\mathrm{PI} 3 \mathrm{~K} / \mathrm{mTOR}$ kinase inhibitor with robust activity in cancer models driven by the PI3K pathway. Mol Cancer Ther. 2011; 10: 2426-2436.

[23] de Bono JS, De Giorgi U, Massard C, et al. Randomized phase II study of AKT blockade with ipatasertib (GDC-0068) and abiraterone $(\mathrm{Abi})$ vs. Abi alone in patients with metastatic castration-resistant prostate cancer (mCRPC) after docetaxel chemotherapy (A. MARTIN Study). J Clin Oncol. 2016; 34(15 Suppl): 5017.
[24] Spratt DE, Zumsteg ZS, Feng FY, et al. Translational and clinical implications of the genetic landscape of prostate cancer. Nat Rev Clin Oncol. 2016; 13: 597-610.

[25] de Leeuw R, Berman-Booty LD, Schiewer MJ, et al. Novel actions of next-generation taxanes benefit advanced stages of prostate cancer. Clin Cancer Res. 2015; 21: 795-807.

[26] Boutros PC, Fraser M, Harding NJ, et al. Spatial genomic heterogeneity within localized, multifocal prostate cancer. Nat Genet. $2015 ; 47$ : 736-745.

[27] Massie CE, Mills IG, Lynch AG. The importance of DNA methylation in prostate cancer development. J Steroid Biochem Mol Biol. 2017; 166: 1-15.

[28] Daniunaite K, Jarmalaite S, Kalinauskaite N, et al. Prognostic value of RASSF1 promoter methylation in prostate cancer. $\mathrm{J}$ Urol. 2014; 192: 1849-1855.

[29] Zhang W, Shu P, Wang S, et al. ZNFl54 is a promising diagnosis biomarker and predicts biochemical recurrence in prostate cancer. Gene 2018; 675: 136-143.

[30] Zhang W, Jiao H, Zhang X, et al. Correlation between the expression of DNMT1, and GSTPl and APC, and the methylation status of GSTPI and APC in association with their clinical significance in prostate cancer. Mol Med Rep. 2015; 12: 141-146.

[31] Nagy B, Szendrői A, Romics I. Overexpression of CD24, c-myc and phospholipase $2 \mathrm{~A}$ in prostate cancer tissue samples obtained by needle biopsy. Pathol Oncol Res. 2009; 15: 279-283.

[32] Bharali DJ, Sudha T, Cui H, et al. Anti-CD24 nano-targeted delivery of docetaxel for the treatment of prostate cancer. Nanomedicine 2017; 13: 263-273.

[33] Jimeno A, Gordon M, Chugh R, et al. A first-in-human phase I study of the anticancer stem cell agent ipafricept (OMP-54F28), a decoy receptor for Wnt ligands, in patients with advanced solid tumors. Clin Cancer Res. 2017; 23: 7490-7497.

[34] Mateo J, Boysen G, Barbieri CE, et al. DNA repair in prostate cancer: biology and clinical implications. Eur Urol. 2017; 71: $417-425$.

[35] Pritchard CC, Mateo J, Walsh MF, et al. Inherited DNA-repair gene mutations in men with metastatic prostate cancer. $\mathrm{N}$ Engl J Med. 2016; 375: 443-453.

[36] Mateo J, Carreira S, Sandhu S, et al. DNA-repair defects and olaparib in metastatic prostate cancer. N Engl J Med. 2015; 373: $1697-1708$.

[37] Clarke N, Wiechno P, Alekseev B, et al. Olaparib combined with abiraterone in patients with metastatic castration-resistant prostate cancer: a randomised, double-blind, placebo-controlled, phase 2 trial. Lancet Oncol. 2018; 19: 975-986.

[38] Roscilli G, Gavory G, Lamartina S, et al. PARP inhibitor MK-4827 is synthetic lethal for tumors with homologous recombination defects associated with ATM-deficiency, PTEN-deletion and microsatellite instability (MSI). Cancer Res. 2010; 70(8 Suppl): 685 .

[39] Sandhu SK, Schelman WR, Wilding G, et al. The poly(ADPribose) polymerase inhibitor niraparib (MK4827) in BRCA mutation carriers and patients with sporadic cancer: a phase 1 doseescalation trial. Lancet Oncol. 2013; 14: 882-892.

[40] Hussain M, Carducci MA, Slovin S, et al. Targeting DNA repair with combination veliparib (ABT-888) and temozolomide in patients with metastatic castration-resistant prostate cancer. Invest New Drugs 2014; 32: 904-912.

[41] Hussain M, Daignault-Newton S, Twardowski PW, et al. Targeting androgen receptor and DNA repair in metastatic castrationresistant prostate cancer: results from NCI 9012. J Clin Oncol. 2018; 36: 991-999.

[42] Cheng HH, Pritchard CC, Boyd T, et al. Biallelic inactivation of BRCA2 in platinum-sensitive metastatic castration-resistant prostate cancer. Eur Urol. 2016; 69: 992-995.

[43] Pomerantz MM, Spisak S, Jia L, et al. The association between germline BRCA2 variants and sensitivity to platinum-based chemotherapy among men with metastatic prostate cancer. Cancer 2017; 123: 3532-3539. 
[44] Nava Rodrigues D, Rescigno P, Liu D, et al. Immunogenomic analyses associate immunological alterations with mismatch repair defects in prostate cancer. J Clin Invest. 2018; 128: 4441-4453.

[45] Beer TM, Kwon ED, Drake CG, et al. Randomized, doubleblind, phase III trial of ipilimumab versus placebo in asymptomatic or minimally symptomatic patients with metastatic chemotherapy-naive castration-resistant prostate cancer. J Clin Oncol. 2017; 35: 40-47.

[46] Kwon ED, Drake CG, Scher HI, et al. Ipilimumab versus placebo after radiotherapy in patients with metastatic castration-resistant prostate cancer that had progressed after docetaxel chemotherapy (CA184-043): a multicentre, randomised, double-blind, phase 3 trial. Lancet Oncol. 2014; 15: 700-712.

[47] Hansen AR, Massard C, Ott PA, et al. Pembrolizumab for advanced prostate adenocarcinoma: findings of the KEYNOTE-028 study. Ann Oncol. 2018; 29: 1807-1813.
[48] Chila R, Guffanti F, Damia G. Role and therapeutical potential of CDK12 in human cancers. Cancer Treat Rev. 2016; 50: 8388.

[49] Bajrami I, Frankum JR, Konde A, et al. Genome-wide profiling of genetic synthetic lethality identifies CDK12 as a novel determinant of PARPl $/ 2$ inhibitor sensitivity. Cancer Res. 2014; 74 : 287-297.

[50] Kari V, Mansour WY, Raul SK, et al. Loss of CHDl causes DNA repair defects and enhances prostate cancer therapeutic responsiveness. EMBO Rep. 2016; 17: 1609-1623.

(Szarvas Tibor dr., Budapest, Üllői út 78/B, 1082 e-mail: sztibusz@gmail.com)

A Semmelweis Egyetem Általános Orvostudományi Kara örömmel tesz eleget annak a hagyománynak, hogy volt diákjait jubileumi díszoklevéllel tünteti ki.

Kérjük ezért azokat az orvosokat, akik diplomájukat az egyetem jogelődjénél, a BUDAPESTI KIRÁLYI MAGYAR PÁZMÁNY PÉTER TUDOMÁNYEGYETEMEN, a PÁZMÁNY PÉTER TUDOMÁNYEGYETEMEN, illetve a BUDAPESTI ORVOSTUDOMÁNYI EGYETEMEN
1944-ben
1949-ben
1954-ben
1959-ben
1969-ben

szerezték meg, és szakterületükön legalább 30 évig dolgoztak, nyújtsák be kérelmüket a platina, rubin, vas, gyémánt, illetve arany díszoklevél elnyerése érdekében lehetöleg 2019. április 30-ig, a következő címre, az alábbi jelentkezési lapon.

A jubileumi díszoklevelek átadására elöreláthatóan októberben kerül sor.

A pontos időpontról meghívó útján küldünk értesítést.

Semmelweis Egyetem Általános - Orvostudományi Kar

Dékáni Hivatal

1085 Budapest, Üllői út 26. vagy 1428 Budapest Pf. 2.

\section{JELENTKEZÉSI LAP \\ arany, gyémánt, vas, rubin és platina díszoklevélhez}

NÉV

(névváltoztatás feltüntetésével)

Születési idő:

Diploma kelte:

Lakcím:

Telefonszám:

E-mail cím:

Utolsó munkahely:

Rövid szakmai önéletrajz:

Aláirásommal hozzájárulok ahhoz, hogy fenti adataimat - az ALUMNI tevékenységgel összefüggésben - a SEMMELWEIS ALUMNI Iroda kezelje.

Dátum:

Aláirásommal hozzájárulok ahhoz, hogy a lakóhelyem szerinti illetékes önkormányzat megkeresésére, kerületi ünnepségre történő meghivás céljából az elérhetőségeim kiadásra kerüljenek.

Kérem a megfelelő részt aláhúzni.

IGEN

NEM

kérelmezö aláirása

A cikk a Creative Commons Attribution 4.0 International License (https://creativecommons.org/licenses/by/4.0/) feltételei szerint publikált Open Access közlemény, melynek szellemében a cikk bármilyen médiumban szabadon felhasználható, megosztható és újraközölhető, feltéve, hogy az eredeti szerző és a közlés helye, illetve a CC License linkje és az esetlegesen végrehajtott módositások feltüntetésre kerülnek. (SID_1) 